\title{
Signifying Trauma in the Post-9/11 Combat Film: The Hurt Locker and In the Valley of Elah
}

\section{Introduction}

This article addresses two Iraq War films, The Hurt Locker (Bigelow 2008) and In the Valley of Elah (Haggis 2007), through the lens of trauma theory. Uniquely, it engages with Slavoj Žižek's account of the Real in its analysis of how victim/perpetrator trauma is signified in their respective narrative structures and visual style. The primary argument is that the pattern of traumatic memory is reflected in their narrative modes. At the same time, it claims that the unfolding narrative of In the Valley of Elah mimics certain forms of trauma treatment, operating in a therapeutic mode for its characters (as well as offering narrative resolution for spectators). Such analysis of trauma differs from other scholarly approaches to these films that have variously considered them from perspectives of: embodiment in the war film (Burgoyne 2012); the ethics of viewing traumatic suffering (Straw 2011); the de-politicisation of torture by the inclusion of posttraumatic stress disorder (PTSD) (Barker 2011); indifference to post-9/11 war films as an inability to respond to the trauma and loss that terrorism poses (Toffoletti and Grace 2010); trauma and the militarised body (Andreescu 2016); and the narration of trauma in Iraq War Films (Kopka 2018).

To some extent Katalina Kopka's analysis is comparable to the argument here because she examines how Kathryn Bigelow incorporates traumatic memory into the narrative fabric of The Hurt Locker. Specifically, she claims that the narrative is 'organized by the principle of repetition compulsion' (2018: 108) in the way that all bomb disposals featured in the film follow a similar structure and there is a mirroring of certain scenes. She also identifies circularity when protagonist, Sergeant William James (Jeremy Renner), returns to Iraq for a further round of duty. A second focus of her study involves the film's distortion of time and space as expressions of trauma (Kopka 2018: 109). However, whereas Kopka engages with Jacques Derrida's concept of hauntology in 
respect of The Hurt Locker, this article centres on Slavoj Žižek's concept of the Real and the way in which the signification of trauma oscillates between the Real and the Symbolic. Expressly, it aligns the structure of the two film narratives with traumatic memory, and identifies symptoms of PTSD in their characters.

\section{Trauma and Film Post-9/11}

Indeed, since the events of September 112001 (9/11), an extensive range of genres increasingly feature traumatised protagonists. From Inception (Nolan 2010) and Shutter Island (Scorsese 2010) through to the Harry Potter franchise (various 2001-11) and Nolan's Batman trilogy (2005-12), traumatised protagonists abound. This recent attention to characters' unstable mental states and harrowing pasts arguably reflects a rising awareness of trauma following 9/11, not only as a result of the immediate experience of the Twin Towers' destruction, but also because of reports of the mental distress endured by army combatants returning from operations in Iraq and Afghanistan, with studies documenting that $20-40 \%$ of returning US military personnel experienced mental health symptoms (Hoge, Auchterlonie and Milliken 2006). Yet, despite scholarly references to the representation of trauma and the use of testimonials in works such as Shoah (Lanzmann, 1985) (which demanded the enactment or reliving of suffering [LaCapra 2001: 187]) as a means to convey the historical trauma of the Holocaust, there are acknowledged difficulties in trying to recreate the actual experience of trauma on screen (Walker 2005: 126). On one hand, Roger Luckhurst suggests that cinema is a 'cultural form closely attuned to representing the discordances of trauma' (2008: 177) and on the other, acknowledges that there are 'limits of traumatic representation inside the frame of classical Hollywood narrative' (2010: 16). In a similar vein, Nick Hodgin and Amit Thakkar liken films about trauma to scarring, noting 'what is reproduced is not the wound itself but a simulacrum of it. The simulacrum of the wound - not the wound itself, the original historic event - that is the focus in the present as we watch that film' (2017: 16).

\section{Žižek, The Real and The Symbolic}


Žižek (2002) considers this dilemma through an extension of Lacanian psychoanalysis, and places trauma in a category termed 'the Real' (an abstract mental experience distinct from the terms 'real', 'reality' and 'realism' as deployed in everyday life but closely affiliated with them), as a form that is resistant to symbolisation (and is therefore discrete from categories that he terms 'the Symbolic' and 'the Imaginary'). He explains that the Imaginary indicates the period of life before language acquisition and the Symbolic encompasses that which may be symbolised (either through language, images or other modes of representation). The Real, however, is that which cannot be fully known or symbolised because it describes a physical experience or feeling rather than a definable object and is an unchangeable reality that in itself is devoid of meaning. For Žižek, such experiences include suffering trauma. While his work draws on that of Lacan, it tends to uniquely centre on the Real and its interplay with the Symbolic (whereas other authors focus on the flux between the Imaginary and the Symbolic [Myers 2003: 29]). As Tony Myers further explains 'If the Symbolic Order is bound together by the signifying chain [...] then we are doomed never to know the world as it really is $[\ldots]$ on the other hand, if the relationship between signifier and signified is arbitrary and unstable, then the character or type of Symbolic Order in which we live is neither permanent nor necessary' (Myers 2003: 24).

Žižek examines this concept in relation to the 9/11 attacks which he contends were a 'direct experience of the Real' (2002: 1) and suggests that, even though encounters with the Real are unpalatable or life-threatening (as occurs in the two films examined here), we have a passion for them (both as spectators and in real-life) because such events remind us we are alive and enable us 'to regain a hold on reality' (2002: 10) as opposed to the simulated world that increasingly surrounds us. He illustrates this passion for the Real with reference to the act of deliberately cutting oneself by claiming that such an act signifies exactly this desire - to provide a 'real' lived experience rather than a virtual (Symbolic) one. Ironically, Žižek suggests that the passion for the Real leads to 'theatrical spectacle' [original emphasis] (2002: 9), whereas over-proximity to the 
gritty reality of the Real destroys what he terms 'the fantasmic space'. Referring to hardcore pornography websites as an example of the latter, he explains that 'when we get too close [for example, by the use of extreme close-ups] to the desired object, erotic fascination turns into disgust at the Real of the bare flesh' (2002: 6).

Even as many scholars and psychoanalysts agree that the actual lived experience of trauma is 'unrepresentable', and therefore falls into the category of the Žižekian Real, the symptoms and effects of traumatic experience are readily deployed in film to signify trauma through specific visual devices, often the flashback. Yet, In the Valley of Elah and The Hurt Locker, two quite different films aesthetically (the former has a slow-paced narrative and entails mostly banal imagery whilst the latter displays faster editing and handheld cinematography, and regularly stages 'theatrical spectacle'), bring the viewer close to the traumatic experience of the Real by their distinctive, if related strategies. These include a variety of visual devices that structure their respective narratives so as to cause them to resemble traumatic memory. In the case of In the Valley of Elah, the conversion of the film's fractured imagery (obtained from a corrupted telephone memory card) from that resembling traumatic memory to that which assumes logic and linearity (here, termed 'narrativised memory') as the chain of events is fully revealed resolves trauma for the characters (and the narrative for the spectator), thereby providing diegetic closure.

The Hurt Locker operates differently since certain of its traumatic images directly access the Real, whilst others conform to Žižek's description of 'theatrical spectacle' (2002: 9). Nonetheless, both types of visuals in this film are horrific, with the former being rendered in extreme close-up (in the same way as the aforementioned pornographic images to which Žižek refers), and therefore becoming uncomfortably too close (for characters and spectators). This results in a rupture of the 'fantasmic space' of war (as adrenalin rush for the character, and as entertainment for the spectator) whilst the latter type are conveyed as spectacular through editing, framing and cinematography. Moreover, the masochistic affinity of The Hurt Locker's protagonist, Sergeant James, for life- 
threatening situations is akin to the desire for self-harm described by Žižek. In brief, the fetishization of traumatic images as spectacle (whereby characters are killed in spectacular display), alleviates the effect of the Real (because their death is aestheticised) whilst the narrative does not provide closure for protagonists (or spectators) in the same way as In the Valley of Elah because, by the end of the film, we learn that James returns to Iraq for another round of duty, thereby effectively forming a circular narrative. The suggestion of trauma therefore fluctuates between the actuality of the Real (indicated for example, by the aforementioned extreme close-ups of blood-spattered dead bodies or otherwise, their complete disintegration) and the signification of the Symbolic (for instance, the collection of explosive devices that James stores under his bed gives meaning to his experience of warfare). Whilst James exhibits a persistent 'passion for the Real' in his fascination with the bomb parts and his own close encounters with death, he finds the harsh reality of warfare untenable (specifically, when he is morally compelled to remove explosives from the body of a child victim), his trauma therefore remaining unresolved. It is with Žižek's consideration of the relationship between the Symbolic and the Real that this article is concerned, in particular, the oscillation between them that becomes evident in the films' multi-layered signification of trauma.

\section{Trauma and Representation}

As stated earlier, a common means for cinema to indicate an individual's trauma is through subjective flashbacks, thereby indicating one of trauma's most significant facets namely, the unassimilated nature of the original event. As trauma scholar, Cathy Caruth explains, 'trauma is not locatable in the simple violent or original event in an individual's past, but rather in the way that its very unassimilated nature - the way it was precisely not known in the first instance - returns to haunt the survivor later on' (1996: 4). The inability to integrate distressing events causes the traumatic memory to replay repeatedly as flashbacks, and hallucinations, which are typically 'sudden, unbidden, emotionally intense sensory experiences (such as visual images or smells) that 
seemingly reinstate the sensory impressions that occurred during the trauma' (McNally 2003: 113). Conversely, there may be complete avoidance of thoughts concerning the original trauma, or alternatively, trauma may manifest as hyper-vigilance where the sufferer is in a constant state of alertness (Luckhurst 2008: 1). Overall, over 20 symptoms are listed as criteria for a diagnosis of PTSD (Hunt 2010: 52-52), a term formally adopted by the American Psychological Association (APA) in 1980, and prompted by the experience of traumatised veterans returning from Vietnam. Even though the symptoms of PTSD are diverse, their common denominator is an extreme stressor that is 'outside the range of normal human experience [and includes] war experience, natural and man-made disasters, rape and sexual abuse and other significantly stressful events' (Hunt 2010: 52). In addition to the APA's definition of PTSD, Nigel Hunt further differentiates war trauma as a particularly complex form of distress that not only encompasses response to traumatic events but may also involve the inability to return to normal civilian life. To those criteria of intrusive reexperiencing, avoidance, emotional numbing, and hyper-vigilance, Hunt therefore adds the effects on return to civilian life, these including aggression, dependence on alcohol, difficulties in employment, drug use, violence, and suicidal tendencies (2010: 9).

Approaches to understanding the relationship between trauma and culture often look back to Freudian perspectives, which ranged from incest theory to the war neuroses but more recently, as in the case of Caruth (1996), focus on narrative's engagement with trauma (both filmic and literary), and the function of literature in testimony (Felman and Laub 1992). Subsequently, the trauma debate has broadened to consider more specifically the relation between visual media and trauma, with Screen Journal including a special issue in 2001 discussing the subject. At the same time, the impact of $9 / 11$ has become an increasingly significant topic for trauma and media theorists alike, its global witnessing implicating visual media as a factor in vicarious trauma (Greenberg 2003; Holloway 2008; Kaplan 2005; Shalev 2007). War trauma has become particularly topical after $9 / 11$ because of the conflicts in Afghanistan and Iraq, which have in turn prompted the 
production of a number of combat films (many of them referencing PTSD). In fact, Martin Barker (2011a) has identified twenty-three films released between 2005 and 2008 that centre on the Iraq conflict. Yet, as he explains, 'all of them, until the very last one in the cycle, bombed at box-office, if they made it there at all - and just about all of them vanished without a trace' (2011a: 1). The poor commercial performance of these films leads Barker to label them as a 'toxic genre', with Douglas Kellner suggesting that 'the box office failure of many Iraq films shows that the experience is too painful for audiences to confront' (2010: 233). Even so, In the Valley of Elah and The Hurt Locker achieved widespread critical acclaim, the first nominated for one Academy Award, and the latter winning six, including categories of Best Director and Best Film.

\section{Trauma and In the Valley of Elah}

In the Valley of Elah traces the dehumanising effects of warfare on US soldiers, whose experiences in Iraq lead them to kill one of their own team, Mike Deerfield (Jonathan Tucker), and the film follows the journey of his father, military veteran, Hank Deerfield (Tommy Lee Jones) as he uncovers the circumstances of his son's death.

Scholarly discussion of the film often focuses first, on the symbolism of an inverted flag, which Hank Deerfield raises at the end of the film to signal the country's state of distress, and second, on the misogyny and corruption displayed by the military criminal justice system (see Barker 2011; Kellner 2010; Prince 2009). Yet, central to the film is the signification of trauma. Inspired by actual events, the film is a dual stranded narrative because it firstly tells of his son's traumatic experience of warfare, and perpetrator guilt associated with the killing and torture of Iraqi civilians. It further reveals the effects of war on the soldiers who murdered him. In uncovering the reasons that led to his son's murder, the film secondly suggests that the father too is suffering from PTSD. This becomes increasingly apparent throughout the film in the latter's emotional detachment when he views the remains of his son, his emotional distance from his wife, the fact that he 
experiences nightmares, and the acknowledgement at the end of the film that he has repressed knowledge of his son's trauma. Even though his traumatic anxiety arises because of his guilt in failing to recognise his son's pleas for help, it may also be a result of the earlier accidental death of his first son, ten years previous, itself a significant stressor. In addition, we learn that Hank Deerfield served in Vietnam, with clues to his military background emerging in his attention to order. Although there is debate concerning the idea that PTSD can be transmitted across generations through secondary traumatisation (Kirmayer, Lemelson and Barad 2007: 10), it is possible that his son's susceptibility to trauma has been transmitted as a trans-generational effect. Such effects may have several implications, but as Kirmayer, Lemelson and Barad explain, 'the child may be rendered more anxious and vulnerable to trauma as a result of parental anxiety, impaired parenting (parental preoccupation, neglect, over-involvement, over-protectiveness), abuse, or other patterns of child rearing' (2007: 10).

Hank Deerfield's repressed trauma is hinted at by a combined visual strategy of distorted video footage and unexpected shocking images of violent death within an otherwise visually banal and slow-paced film. Narratively, these visuals firstly reflect Mike's tendency to record events in Iraq, even those that are normally distressing (perhaps echoing events at Abu Ghraib when the abuse of terrorist suspects was likewise photographed by military police). The other images of violent death that intermittently interject narratively disclose the soldiers' respective suffering of PTSD (one commits suicide, and another kills his wife and dog). At the same time, the footage and recurrent alarming images visually mimic intrusive flashbacks and incoherent traumatic narratives. Mark Straw contends that the spectator also experiences a traumatised subjectivity from an auditory as well as a visual perspective, which 'is implied through [a] technique of disembodied voices accompanying [Hank Deerfield's] scenes when he is depicted on the cusp of sleeping or waking' (2011: 62). Ostensibly, the entire trajectory of the narrative is directed towards converting traumatic 
memory into 'narrativised memory' (and thus resembles the strategies of certain forms of trauma therapy).

The opening credits of In the Valley of Elah accompany what appears to be distorted video footage of various Iraqi locals, the imagery then disappearing completely from view, so that the spectator sees only disjointed, meaningless fragments, accompanied by static noise distortion. This then cuts to a black screen accompanied by a voiceover that states, 'Mike, get back in the fucking vehicle, let's go Mike, now'. Thereafter follows an extreme close-up of Hank Deerfield conversing by telephone and, in response to the words, 'dad! Dad!'(words which are audible to the spectator and which, we presume, are uttered by his son), answers 'I can hardly hear you'. Almost immediately, we realise there has been an elision, as the voice at the other end of the line now states, 'I said your son has gone AWOL', indicating that his son's words were imagined by Deerfield. Further clues to the latter's equivocal mental state become apparent, first, in a shopkeeper's seemingly innocuous comment of 'you gotta trust someone sometime Hank', and second, in his tense, distant relationship with his wife. Their emotional remoteness is often signalled by physical distance, and they are mostly framed separately, or occupy different locations. In addition, when he telephones his wife, their conversation is stilted and awkward, further intimating their strained marriage and corresponding with Hunt's description of trauma victims' relationships in which there is '[a] feeling of detachment or estrangement from others' (2010: 53). The two trauma narratives of father and son are interwoven because the precipitating event for the father addressing his own history is his son's death (which compounds previous distressing events). However, we do not learn the causative agent of the son's trauma until the end of the film.

As Deerfield sets off to locate his son, he removes a photograph of him from a frame, the image displaying his son in military uniform (with its connotations of honour and bravery). Enroute to the army base, he drives past a US flag flying upside down, and stops his car to assist its owner in repositioning it, cautioning the man that flying the flag in such a way is an international 
distress signal. Both of these events are significant in relation to Žižek's account of the relationship between the Symbolic and the Real - Deerfield initially corrects the flag's positioning in the belief that there is no sign of distress, and temporally removes the photograph of an apparently brave son from its frame (to use as a means of identification) and therefore changes the original signification of the two symbols. However, both actions emerge as examples of the Symbolic 'cutting' into the Real (Myers 2003: 25) as it becomes evident that trauma underpins each of them - the reversal of these at the film's end conversely indicates an acknowledgment of both his own, his son's, and the nation's trauma and therefore a return to the Symbolic. Thereafter, Deerfield continues his journey and when he stops to sleep, the screen cuts to black, and once more, the words 'dad, dad' are audible. A close-up of Deerfield's awakening face indicates that he has again been dreaming, and, as he surveys his surroundings, he realises (along with the spectator) that a young boy in the near vicinity, also shouting 'dad', may have triggered his flashback.

Deerfield's arrival at the army base where his son was stationed now reveals that he himself was a serving sergeant, explaining the reasons behind earlier indications of his meticulousness. We witness this via close-ups, for example, of the way he makes his bed with military precision, carefully polishes his shoes, places them on the floor, and then adjusts them slightly so that they line up exactly. As Deerfield checks through his son's belongings, a subjective camera shot reveals Mike's mobile phone that he discreetly pockets. Thereafter, a technician offers to download the firedamaged mobile's corrupted media files, these presenting as fractured, disjointed images and static noise. The phone's address book additionally lists a strip club that Deerfield visits in search of Mike. Here, the red toned lighting and erotic imagery not only convey the sleaziness of the club but also mediate nightmarish effects, as if these sights too are an incursion into his son's repressed unconscious.

During his quest, Deerfield encounters the film's second protagonist, female police officer Detective Emily Sanders (Charlize Theron), whom he overhears deal curtly with a young woman 
reporting that her husband has drowned their family pet. In describing the attack, the woman indicates that her husband, a soldier too, is in a mentally unstable state, further compounding the film's references to war trauma. Deerfield also meets up with a former military CID friend hoping to recruit his help in investigating his son's disappearance. It is in conversation between the two men that we learn that Deerfield's first son, David, had died ten years earlier in a helicopter crash.

Mostly, the narrative unfolds slowly and the film is visually understated (in its neutral colour palette and slow-paced editing), which renders its scenes of death more intrusive, this pattern replicating both the nature of traumatising events and the invasive effect of the flashback on normal life. As Susannah Radstone explains, 'it is the unanticipated, unimagined quality of certain events that renders them so shocking. The mind has not prepared itself for an event that traumatizes' (2003: 119). This allusion to the flashback is therefore not conveyed as subjective traumatic memory, as is often the case in films concerning trauma, and so is not immediately obvious. Rather, it occurs through the narrative structure whereby scenes of gruesome death are abruptly interspliced with unspectacular ordinary scenes. The first example of such imagery occurs when Deerfield views his son's remains - the film presents the charred fragments as one of a series of isolated horrific instances in an otherwise visually mundane sequence. We first hear the pathologist's voiceover commenting that 'the body was dismembered before it was burnt', before Deerfield's point of view reveals a number of small, almost unrecognisable, body parts lying pathetically on a tray. The camera cuts between Deerfield's grim facial expression and close-ups of the burnt remains, and, though Deerfield appears somewhat shaken, he nonetheless continues to ask questions in an official way (rather than displaying emotion as one might expect). For instance, when the pathologist comments on the presence of multiple stab wounds, Deerfield immediately asks, 'How many stab wounds?' The pathologist is transiently taken aback by Deerfield's calm questioning, the latter further pressing him, 'one knife or several?' and arguably displaying emotional numbing. The use of similar disturbing imagery recurs throughout the film where its slow 
pace continues to be interspersed with images of violence - sometimes these manifest in the footage that Deerfield receives from the technician, with indistinct images of burnt bodies that the soldiers make fun of (they pin a sticker of a sinister grinning face to one of the burnt bodies). 'See how the clothes aren't burnt. It's really weird dad' we hear Mike say, his voice shaky and seeming emotionally affected as the footage freezes on what appears to be a girl's burnt face. A further example of intrusive imagery constructed in the manner of a traumatic flashback occurs when another soldier, Bonner (Jake McLaughlin) (one of those caught up in Mike's murder) commits suicide by hanging himself. A close-up of the soldier's ashen face and purple lips amplifies the violent nature of his death, and reveals a black bruise encircling his neck, before a cut to a side-on medium close-up then highlights a distinct indentation where the rope had constricted his neck. A third example occurs when the wife of a soldier (the same one who killed his pet dog) is found strangled and drowned in the bath. The spectator hears Detective Sanders gasp (because she had previously dismissed the woman's fears), before observing the woman's body in the bath, the scene mediated as distressing by a medium close-up from Detective Sanders' point of view. While these images in themselves merely signify the experience of the soldiers' trauma by suicide and murder, the film constantly brings the spectator closer to Žižek's account of the Real in the way that they disrupt an otherwise banal narrative. In other words, the unexpected rupture of the narrative replicates both the nature of trauma and the traumatic flashback.

However, the most significant mode by which the narrative structure mimics traumatic memory occurs in the film's use of mobile phone footage. Intermittently, a technician emails Deerfield the images, which are barely discernible and highly distorted. Alongside the images we repeatedly hear Mike's voice saying 'you gotta get me out of here dad'. Deerfield receives the phone footage throughout the film, and these likewise take the form of flashbacks in their fragmented flashes of the past, upon which Deerfield attempts to impose some coherency. At first, it seems impossible to work out what has happened, but as the film progresses, it becomes slowly 
apparent that Mike enjoyed violence and killing, though at the same time, experienced guilt and distress. An early feature of the phone recordings is of Mike's convoy driving through an Iraqi village when we hear an audible thud, followed by shouts of 'don't stop the vehicle'. Another soldier, Private Ortiez (Roman Arabia) later divulges to Hank Deerfield that the thud was the sound of the vehicle hitting a child, though Ortiez adds that he believed it was a dog that they had killed (likely, as a coping mechanism). Mike is also seen torturing prisoners, conveyed through disjointed images of flashes of blood and the sound of screaming. During these sequences, we hear his voice saying, 'where does it hurt, right there?' followed by further screaming, and we learn that he inserted his hand into a prisoner's wound, earning himself the nickname, 'Doc'. Periodically, Mike's grinning face is visible, which his father finds difficult to view. In a similar way to which the narrative is itself interspersed with shocking images, the incoherent phone footage thus resembles traumatic memory. The latter eventually becomes indistinguishable from the father's nightmares, which constantly replay the footage and in which we now hear Mike say 'I'm so mad with dad'. In this respect, Hank Deerfield's nightmares give clues to his state of distress.

The way in which the film's protagonists come to terms with their experiences of combat and loss corresponds with various interventions for the treatment of PTSD, which generally rely on re-integrating the traumatic event through re-exposure and re-narrativization (see Foa et al 2009). This is because trauma narratives are often fragmented (as symbolised by the phone footage). As McNally observes, 'The psychiatrist Bessel van der Kolk believes that the emotional intensity of trauma often makes it hard for survivors to piece together a coherent narrative of what happened' (2003: 135). McNally then goes to report one study by Foa that defines narrative fragmentation as, 'repeated phrases, speech fillers, and unfinished thoughts that disrupted the smooth flow of the story' (2003: 135). In this case, the assembly of the distorted footage progressively uncovers the chain of events that led to Mike's death, culminating in Deerfield's slow realisation that his son was suffering trauma too but, at the same time, was a torturer. The process of reassembling the footage 
into a logical story, and the revelations that this brings, is analogous to regression analysis where patients undergoing hypnotherapy recall repressed unpleasant memories. In this way, while serving to signify the nature of traumatic memory, re-narrativisation imposes a coherency on the imagery and on Hank Deerfield's own repressed recall. The footage is therefore more than merely a narrative device and is important in other ways relating to the signification of trauma - first, its recording of the various events that affected the soldiers serves as a form of testimony for Mike. As Kirmayer, Lemelson and Barad note, narratives told by the sufferer (and simultaneously, in this case, perpetrator) are important in dealing with trauma when they 'are witnessed and acknowledged by others' (2007: 15). Significantly, the signs of perpetrator trauma are mostly absent in the films discussed here. Indeed, as Raya Morag (2007) explains, cinema tends to represent perpetrator trauma similarly to victim trauma even though there are conspicuous differences in real-world examples. For the perpetrator, these differences include: the experience of profound moral contradictions rather than intrusive memories; a preoccupation with the space where the event took place (as opposed to the time); empathy and possible mourning for the victim of trauma; and a confession rather than a forgetting of their accounts (Morag 2007: 16-19). Here, Mike exhibits some evidence of perpetrator trauma in his obsession with the place where the primary causative event - the vehicle hitting a child - occurred (a site that is frequently returned to during the film). One might argue that his depiction primarily as a trauma victim is a way of showing a once (but lost) moral certainty/value system though, in the final instance, neglects the trauma experienced by Iraqi civilians.

The second way in which the footage is important to the signification of trauma is in Hank Deerfield's constant replaying of it as an attempt not only to understand what happened to his son, but arguably at mastery of the unfolding situation, a means to regain control. Kathy Smith outlines an analogous scenario in relation to $9 / 11$ when news channels constantly replayed footage of the Twin Towers' collapse. Likening this to Freud's 'fort-da' scenario (Freud 2001b: 15), (in which a 
child repeatedly throws a cotton reel with a string attached to it, only to continually retrieve it), she explains,

In terms of repetition-compulsion, the connection between Freud's theory and the media representation of September 11 is clear. One of the lasting images [...] is the image of the second plane impacting on the second tower, replayed again and again throughout the day and over the days that followed, in a global attempt to admit its possibility and to come to terms with the act (Smith 2005: 67).

Geoff King advances this analogy further by arguing 'television has a (limited) capacity to 'contain' or reduce the impact of momentous events' (2005: 56) in its imposition of continuity on fragmented imagery by filling in the gaps.

Thirdly, the footage enables the father to address his own guilt in denying Mike's trauma that he had tried to communicate by telephone, the admission of which Hank has repressed. We realise this when, in the closing scenes of the film, Hank has a flashback of Mike phoning him, the footage and his own memory still entangled. It becomes clear that the words heard at the film's outset, 'dad you gotta get me out of here, something's happened' were his son's plea for help. In this final re-narrativising of events, we then hear his father's response in his flashback - 'that's just nerves talking son'- the implication being that he ignored his son's cries for help. 'Something happened Dad' Mike says, to which his father responds, 'for Christ's sake!' (implicitly suggesting that Mike should 'pull himself together').

Finally, the nature of the footage, with its fragmented flashes and unreal nature offers an insight into the experience of disassociation as a traumatic feature. According to Kirmayer, Lemelson and Barad, '[i]n addition to symptoms related to fear and anxiety, the psychological consequences of trauma may include disturbances of memory, identity, and perception termed dissociation [italics in original]' (2007: 7). As Hunt and McHale further elucidate, 'The problem with traumatized people is that they do not have the story of the event that caused the trauma. The 
memories are often fragmented or disassociated; they do not fit together very well' (2010: 53). McNally notes that dissociative symptoms include, 'derealization, a strange, dreamlike sense that one's surroundings are unreal; depersonalization, a sense of being disconnected from one's own body; a sense that time is either slowing down or speeding up; and amnesia, an inability to recall important aspects of what happened [original emphasis]' (2003: 172). These effects are apparent in the phone footage, in which the images freeze, transiently speed up, and elide certain incidents, so that it is impossible to make sense of events and there is an impression of disconnectedness.

Deerfield's and Sanders's quest to resolve Mike's death eventually leads to Corporal Penning's (Wes Chatham) confession - in an unemotional voice, he recounts the events of the night that Mike died, and then states, equally impassively, 'and I look down and I'm stabbing him'. Penning then relates how they dismembered the body, his face still blank, and comments 'We would have buried the parts, but it was late and we hadn't eaten'. He is therefore cold and emotionally detached about the way that he describes Mike's murder and appears undisturbed by it. Thereafter, he recounts the story of how Mike tortured a prisoner, and laughs, commenting that, 'it was pretty funny'. Therefore, he demonstrates symptoms of victim trauma as well, especially in respect of emotional numbing and detachment.

Towards the end of the film, as Hank Deerfield gets in his truck to return home, he seems to experience hallucinations and the footage appears to replay once more. However, it is now uninterrupted and coherent, and he sees Mike's vehicle hit a child (as if literally seeing clearly and understanding the chain of events which led to his son's mental state). Ultimately, the whole sequence becomes visually coherent with Deerfield's unconscious denial of its details now reversed. Thus, it becomes apparent that Deerfield has been repressing his own guilt for not acknowledging Mike's trauma, illustrating that, as Žižek suggests, 'in order really to forget an event, we must first summon up the strength to remember it properly' (2002: 22). At the same time, 
one might argue that the revelation of the child's death and the implication that Mike was troubled by it is ideologically inflected and detracts from the fact that he was a torturer and killer.

In the film's closing scenes, Deerfield replaces the photograph in the frame that he had removed at the outset, ostensibly reconfiguring the mythology of his son's heroism and accepting his shameful actions. The film ends with Deerfield taking a flag that his son has mailed to him, and flying it upside down, metaphorically acknowledging his own distress but also symbolising the immoralities of the Iraq War. Deerfield thus returns both son and country to the Symbolic, the now fully coherent narrative also indicating a shift from the Real to the Symbolic. In this way, the film offers some closure and affirms that Deerfield has come to terms with the limitations of human nature.

\section{Trauma and The Hurt Locker}

The visualisations in In the Valley of Elah depend on exposing the spectator to the precipitating sources of the soldiers' trauma through scenes of extreme horror. Comparable examples of spectacular death occur in the early scenes of The Hurt Locker, triggering similar symptoms of trauma in the soldiers of a bomb disposal unit. As noted, The Hurt Locker follows the macho sensibilities of a bomb disposal squad leader, Sergeant James, who replaces another soldier, Sergeant Thompson (Guy Pearce) when the latter is killed disarming a bomb. Thompson's death particularly affects one member of the unit, Owen Eldridge (Brian Geraghty), who becomes obsessed with dying and exhibits typical symptoms of PTSD. Conversely, Sergeant James seems to thrive on extreme risk and has a complete disregard for danger, imperilling the lives of those around him. This leads Barker to contend that he is 'the living embodiment of posttraumatic stress disorder, but who is treated by the film as not disordered at all' (2011: 157). Guy Westwell, on the other hand, claims that, '[James] is embarked on a trajectory that will lead either to his own death or to nervous breakdown [...] Put simply, James's emerging combat stress extenuates his love of war' 
(2011: 30). Certainly, even if he does not suffer in the same way as Eldridge, or display all the typical signs of stress, James drinks excessively, and is violent. Moreover, though he survives several high-risk incidents to return home, in line with Hunt's (2010) criteria for diagnosing war trauma, he finds it difficult to adjust to civilian life. The film ends with his return to Iraq for a second round of duty, the implication being that he is dependent on the excitement of near-death experiences. Indeed, a central motif of the film is his 'addiction' to war. Rather than solely mimicking traumatic flashbacks, as In the Valley of Elah, The Hurt Locker also fetishizes potentially traumatising events through the deployment of spectacular effects, including slowmotion explosions, impact aesthetics, and scenes of violent death that are dwelt upon by extended editing sequences. In this way, the use of spectacle both draws attention to, yet covers over the trauma of loss. As Thomas Elsaesser comments, 'the affinity between trauma and fetish ('nothing there'), [...] in turn implies a disjuncture between seeing and knowing' (2001: 200). In other words, 'spectacle draws attention to [...] traumatic events [...] but simultaneously disavows them [...] through the pleasurable experience of its aesthetic display' (Pheasant-Kelly 2013: 14).

The first of these spectacular instances occurs within the first five minutes of the film when the bomb disposal unit's first leader, Sergeant Thompson is killed, and given that Guy Pearce is a major star, is completely unexpected for the viewer (as well as other characters). This shock initiates a semblance to real life traumatic episodes, namely, their unexpectedness. Thompson's death occurs in a noisy, crowded street, its sense of chaos enhanced by handheld unsteady camerawork that features sudden erratic zooms. Concurrently, panicked shouting and blaring sirens pervade the establishing mise-en-scène, the cumulative effect of which is to immerse the spectator in the hectic setting of Iraq. The film depicts the attempt to defuse the bomb that kills Sergeant Thompson as a macho event, even a phallic one - 'pretend it's your dick' Thompson tells fellow soldier, Sanborn (Anthony Mackie), who is operating a robotic vehicle remotely to disengage the bomb. (The breakdown of an attached trailer 'built by the US army' signals criticism of technology 
deployed in Iraq). Close-ups of Thompson as he dons a protective suit to manually defuse the bomb encourage spectator identification, and therefore intensify one's sense of outrage as the bomb explodes and kills him. We also experience his point of view as he slowly approaches the explosive device. 'Nice and hot in here' he comments, his voice sounding distorted within the protective facial unit and the amplified sound of his laboured breathing further eliciting viewer empathy by drawing us in closer to his claustrophobic experience. Even as the camera cuts to long shot, we are made aware of his laboured breathing, which now serves as a tension-building device. Added to this, inconsequential banter between Thompson's colleagues, Sanborn and Eldridge, gives way to anxiety as Eldridge suddenly notices an Iraqi civilian operating his mobile phone. Rapid editing between Sanborn, Eldridge, Thompson, and the Iraqi man further escalates the sense of anxiety as Eldridge repeatedly commands the latter to 'drop the phone'. Just as Thompson begins to run away from the bomb, an extreme close-up of the Iraqi man reveals him frantically activating his mobile to trigger an explosion. Thompson is thrown forward by the resultant blast, which is conveyed in a scene of spectacular devastation using slow motion effects. A cut to long shot displays the detonation once more, again occurring in slow motion, as debris seems to fly out towards the spectator. Smaller details of the blast's effects are further disclosed in slow motion, such as dust stirring atop a car roof, and thereafter, the blast is repeated numerous times from different perspectives, so that it appears to be happening more than once. Intercutting occurs between these various slow motion scenarios before a return to normal speed shows Thompson lifted up in the air by the explosion, the interjection of normal film speed heightening its shock effect. This mode of filming and editing is typical of the action film, and creates what Geoff King describes as 'an impact aesthetic' (2000: 101) (whereby action occurs towards the spectator and is repeated). The effect is to prolong and accentuate the spectacular aspects of the explosion, made especially prominent in a film that otherwise adopts a handheld style of cinematography. As Žižek explains, the striving for the 'real thing' (as evidenced in the popularity of reality TV and snuff movies) that 
'culminates in the thrill of the Real as the ultimate 'effect'" (2002: 12) (in this case, attempted through simulating a documentary style of camerawork) is contradicted by the paradoxical projection of the aforementioned sequence as theatrical spectacle (Žižek exemplifies such a paradox with reference to spectacular terrorist acts [2002: 9]). The spectator is thus encouraged to enjoy this encounter (albeit fictionalised) with the Žižekian Real (Thomas's death) while in its visual celebration of combat death, the scene contributes to the representation of a masculinised heroism that is sustained throughout the film.

On his first day as Thompson's replacement, Sergeant James also has to disarm a bomb and duly dons the bomb suit, the same laboured breathing, and subjective camerawork suggesting to the spectator a similar outcome as for Thompson. James, however, appears undaunted, and strides purposefully down the street where a bomb is allegedly rigged. His reckless behaviour continues throughout the film, and we learn that he collects souvenir wiring from his near misses. He thus seems resistant to suffering trauma, though later, the suffering of all of the soldiers becomes increasingly apparent. James eventually shows signs of emotional disturbance as well after befriending a young Iraqi boy, nicknamed 'Beckham', from whom he buys DVDs, but later discovers dead.

However, as noted, the first intimations of PTSD surface in the character of Eldridge, initially, in his seemingly innocuous conversations about death. He becomes increasingly preoccupied with his own mortality, and in one scene asks Colonel 'Doc' Cambridge (Christian Camargo), 'what if all I can be is dead on the side of an Iraqi road?' At the same time, he obsessively plays a video game based upon a violent replication of warfare. As Cambridge presses him further about his feelings (since he is an army doctor), Eldridge takes up his rifle and, pretending to shoot, repeats, 'here's Thompson, he's dead... he's alive... he's dead... he's alive', erratic shifts in camera framing to close-up being synchronised with his comments and further accentuating his disturbed mental state. 
James too, though initially appearing resilient to trauma, is affected profoundly by 'Beckham's' death. Beforehand, the film demonstrates James's toughness by highlighting the potential strain of each bomb-disarming scenario. In such situations, the 'heavy breathing' device and point of view perspectives, as well as sudden accelerated zooms to close-up contribute to the impression of tension. Rapidly panning, deliberately unsteady camerawork, and fast editing, together with constant diegetic background shouting add still further to the unease. Amidst these typical scenes of confusion, James's decisive figure behaviour, despite being hampered by the bomb suit, consistently marks him as unfazed by situations that other soldiers seem to find stressful. In one such scenario, he calmly extinguishes a blazing car, its suspension visibly weighed down with a suspected bomb. On discovering its boot full of explosives, James drops his crowbar and exclaims 'oh god', the camera cutting to close-up as it pans across the massive device. He then alarms his fellow soldiers by removing the bomb suit. As he searches for the detonator, long shots intercut between each of the soldiers, and the on-looking Iraqis, the constant unsettling camerawork adding to the anxiety. The soldiers' visible agitation, especially of Eldridge, who witnessed the detonation of the bomb that killed Thompson, heightens the drama still further. At the same time, James struggles to trace the wires leading to the bomb, and the claustrophobic framing inside the car, together with the amplified sounds of his breathing, convey his mounting frustration and perilous situation. Sanborn adds to this pressure by repeatedly warning James that they are in danger (leading James to discard his headset in order to focus on his task), while extreme close-ups of the wiring that James is trying to fathom out accentuate the strained atmosphere. As he slowly and carefully removes a suspect radio from the car, he inadvertently activates the windscreen wipers, which startle both him and the spectator. Extreme close-ups of him working within the cramped hot confines of the car, sweat dripping from his face, are intercut with long shots of three Iraqis standing atop a minaret balcony, thereby replicating the earlier scenario of Thompson's death, and thus once more priming the viewer (and the other soldiers) for a similar outcome. 
However, James successfully detaches the detonator and tosses it to the ground. The film therefore persistently builds on the opening traumatic scene in which Thompson was killed, always inviting the spectator to experience the anxieties that the men undergo, and to identify with the soldiers in their mistrust of all Iraqis.

An equally tense situation unfolds as the trio are ambushed in the desert - Eldridge's mental state deteriorates still further when they run out of ammunition and James instructs him to retrieve more supplies from one of their dead colleagues. However, when Sanborn loads the cartridge, it fails to operate properly because it is coated in blood, leading James to ask Eldridge to remove the blood. Eldridge appears visibly distraught and camera close-ups frame him tightly, accentuating his panic-stricken state. $\mathrm{He}$ is then so emotionally affected that he is unable to decide whether a goatherd and his animals just visible in the distance constitute a threat, and asks James if he should shoot them. 'Your call' responds James. Though Eldridge appears unsure, he fires off a round of ammunition anyway, before the camera cuts to reveal the dead 'goatherd' holding a rifle (indicating that Eldridge made the right decision, but by luck rather than judgement). Later, back at the base, the men get drunk, and punch and wrestle each other as a way of relieving tension. Here, James confesses that he was once married and is now divorced, thereby indicating the personal impact of being a soldier. He also displays bizarre behaviour, lying on his bed whilst fully armoured with the bomb suit, and storing his 'near-miss' bomb components as souvenirs. If these details might be construed as symbolising James' record of success and heroism and his obsession with dangerous situations, they also evidence encounters with the Real - that is, his near death experiences and are relevant to a signification of war trauma. As Hunt (2010) states, war trauma has a broader range of symptoms than PTSD, including boredom, aggression, and substance abuse and an inability to adapt to home life (an aspect that manifests later when James temporarily returns to civilian life).

Furthermore, James becomes more obviously emotionally affected when on his next mission to pick up unexploded bombs from a warehouse. The use of subjective camera as the soldiers 
investigate the abandoned warehouse again serves to convey their apprehension, the camera peering around corners and once more exposing the spectator to the stresses that they endure. James is the first to discover 'Beckham's' body, which has been surgically implanted with explosives. Here, the film conveys disturbing imagery using a visual strategy of disgust. A close-up focuses on the boy's bloody torso, crudely stitched together, and encasing a bomb. 'Ever see a body bomb before?' Sanborn asks Eldridge. Thereafter, James plans to detonate the body while the other soldiers including Eldridge, Sanborn, and Doc Cambridge wait outside. Doc converses in Arabic with the locals there, and, to the spectator, who is now conditioned, like the soldiers, to be suspicious of all Iraqis, seems naive about their motivations.

Extreme close ups of 'Beckham's' face cut to close-ups of James's face to convey his physical, moral and mental revulsion (the corpse is decaying, indicated by the flies buzzing around). Though James first plans to attach further explosives to the boy's body he then decides to cut it open to defuse the internal bomb (in order to return 'Beckham' to his family, as an act of respect). The use of extreme close-ups throughout accentuates the ethically repellent act of child murder and provides an example of the Real akin to Žižek's description of hardcore pornography. In other words, despite James's seeming desire for the 'adrenaline fix' of the Real, he finds proximity to it revolting. This proximity is achieved by extreme close-ups which show James inserting his pocketknife under each stitch holding the wound together, before he slides his hand into the boy's abdomen - sound effects further heighten the sense of disgust so the spectator is duly situated close to the traumatic event. In this respect, as Myers explains, 'the Real is meaningless and senseless - it just persists, and meaning can only be found within the reality of the Symbolic Order' (2003: 26). As James exits the warehouse carrying the boy's body, 'Doc' Cambridge continues to converse politely with the Iraqi locals, in the belief that they are innocent, yet, as they depart, a bomb explodes, and Cambridge disappears from view. Once more, the camera position situates the spectator alongside the other soldiers inside the vehicle, watching the explosion, and thereby 
exposes us to the same trauma. At this point, Eldridge rushes out shouting, 'IED... Cambridge...where's Cambridge? C'mon Cambridge we gotta go', seeming to deny the fact that Cambridge has been killed. Rapid editing and unsteady camerawork that cuts between the blast and Eldridge's distraught face mediate his distress as he breaks down in tears. The incident affects James too, and when he later goes in search of those responsible for the boy's murder, he begins to show signs of emotion, stammering in confusion when confronting one possible suspect in the realisation that the polite and genteel local man whose home he has broken into is clearly not the boy's killer.

This pattern of intermittent stressful incidents continues to structure the film, each event culminating in a scene of spectacular death. Another instance occurs when the bomb disposal unit carries out a post assessment after a suicide bomb is detonated. Yet again, the viewer is immersed in the carnage - as the soldiers' torches illuminate bodies lying among the burning wreckage, we see victims bleeding and limbs blown off, accompanied by diegetic sounds of screaming and crying. The film therefore purposefully exposes the spectator to the same traumatic experiences as the soldiers. Thereafter, we see Sergeant James in full combat gear, crying and curled-up in the shower.

A final traumatic event occurs as a suicide bomber pleads for someone to remove the bomb that encases him. James duly dons the bomb suit, but realises that the bomb has a timer attached and there is insufficient time to remove the locks of the casement enclosing the victim. Extreme closeups of each padlock as James attempts to cut through them with bolt-cutters intercut with close-ups of first James's, and then the bomber's anguished faces. The escalating commotion of the suicide bomber crying in Arabic, Sanborn screaming through the headset, and James shouting at them both, compounds this visual confusion. However, James is unable to remove the bolts, and has to leave the man to die, the blast once more represented as slow motion spectacle with the same 'impact aesthetics' that characterised the earlier explosions. 
Different to In The Valley of Elah, the film does not offer any resolution of trauma (which remains solely the province of American soldiers), and in James' case, is implicitly celebrated as the point of origin for his reckless/heroic acts. As noted, James is unable to adapt to civilian life, this inability sketched through a mundane mise-en-scène of domesticity - for example, when shopping in a supermarket, extreme low- and wide-angle shots reveal endless rows of products, the overwhelming choice made to seem meaningless after having witnessed such raw violence. Once home, he constantly recounts his combat experiences to his partner who is otherwise preoccupied with domestic matters and seems unable to relate to him. The film ends with his return to Iraq, and the camera cuts to him dressed in the bomb disposal suit in a scene almost identical to the one opening the film, therefore suggesting his desire for the Real and a cycle of trauma from which there is no reprieve.

\section{Conclusion}

In sum, both films centre visual attention on the precipitants of trauma, with these conveyed as shocking spectacle. Generally, they each rely on mediating the effects of trauma through figure behaviour, these symptoms consistent with the generally accepted criteria for diagnosing PTSD, namely, emotional numbing, avoidance, and hyper-vigilance rather than the subjective experience of trauma (for example, we rarely experience the protagonists' flashbacks). In the Valley of Elah compounds the suffering of combat stress through its narrative structure, with mobile phone footage and repeated gruesome visuals utilised to simulate the actual experience of flashbacks. In addition, its trans-generational strands of traumatic experience are interwoven, whilst The Hurt Locker fetishizes war trauma through spectacular, explosive imagery. In the latter, the squad persistently display aggressive tendencies, drink excessively, are emotionally volatile, and have unstable external relationships. Several break down completely and James, in particular, is obsessed with violence, sleeping in his bomb disposal suit, and storing defused bomb souvenirs under his bed. He also has trouble returning to civilian life, in line with Hunt's (2010) designation of war trauma. The 
construction of the narrative, with its unexpected, intrusive, and violent imagery, replicates the characteristics of the traumatic flashback. In other words, akin to the fragmented mobile phone footage in In the Valley of Elah, these instances are 'sudden, unbidden, emotionally intense sensory experiences (such as visual images or smells) that seemingly reinstate the sensory impressions that occurred during the trauma' (McNally 2003: 113). Overall, while both films display certain inadequacies in expressing traumatic experience, they nonetheless they give viewers some insight into the causes and effects of war trauma.

Even so, the two films present a solely American-centric perspective that only marginally addresses perpetrator trauma, and as Martin Barker suggests, 'the appeal of PTSD was that it made those who could be said to suffer it, innocent [original emphasis]' (2011b: 44), an aspect that he argues applies to these two films. They also fail to acknowledge other victims of the Iraq War for, as Hunt notes, civilians too suffer similar traumatic stress to soldiers but 'for civilians traumatised by war [...] in many ways it is worse, because while the soldier has some limited control over his actions, the civilian has no such control, and the traumatic response is linked to the degree of control one has over a situation' (2010: 11). Generally, one might argue that In the Valley of Elah provides a more nuanced, layered film in its signification of trauma via: its unique device for the disruption of a linear narrative structure that mimics traumatic memory; the implication of transgenerational trauma; and reference to civilian trauma and suffering. Conversely, The Hurt Locker promotes mainstream tropes of spectacle in its cinematography and editing, and celebrates heroism and macho masculinity in its characterisation of Sergeant James. Both films relegate the experience of trauma and war to the realm of the individual and are devoid of a fully contextualised political 'reality'. If they illustrate the paradox of the Žižekian Real in the war genre, namely, the mediation of trauma as both spectacle and site of horror, and its intermittent intersection with the Symbolic, the two films promote identification and empathy with protagonists who are presented as victims of traumatic stress, and neglect both perpetrator and civilian trauma. As Westwell notes 'By such 
means a reversal of power relations is effected, with the Americans portrayed as imperilled, powerless and victimised, in contrast to the realities of the balance of power between an insurgency and the world's most powerful army' (2011: 27).

\section{Bibliography}

Andreescu, F., 2016. War, Trauma and the Militarized Body. Subjectivity, 9(2), 205-223.

Barker, M., 2011a. A Toxic Genre: The Iraq War Films. London: Pluto Press.

Barker, M., 2011b. 'America Hurting': Making Movies About Iraq. In P. Hammond, ed. Screens of Terror: Representations of War and Terrorism in Film and Television since 9/11. Suffolk: Arima Publishing, 37-50.

Batman Trilogy. 2005-2012. Dir. Christopher Nolan. US.

Burgoyne, R., 2012. Embodiment in the War Film: Paradise Now and The Hurt Locker. Journal of War and Culture Studies, 5(1), 7-19.

Caruth, C., ed., 1995. Trauma: Explorations in Memory. Baltimore and London: Johns Hopkins University Press.

Caruth, C., 1996. Unclaimed Experience: Trauma, Narrative, and History. Baltimore and London: Johns Hopkins University Press.

Dodds, K., 2008. Hollywood and the Popular Geopolitics of the War on Terror. Third World Quarterly, 29(8), 1621-1637.

Elsaesser, T., 2001. Postmodernism as Mourning Work. Screen, 42(2), 193-201.

Felman, S. and Laub, D., 1992. Testimony: Crises of Witnessing in Literature, Psychoanalysis and History. London and New York: Routledge.

Foa, E., Keane, T., Friedman, M., and Cohen, J., eds. 2009. Effective Treatments for PTSD: Practice Guidelines from the International Society for Traumatic Stress Studies. London and New York: Guilford Press. 
Freud, S., 2001a. An Infantile Neurosis and Other Works: The Standard Edition of the Complete Psychological Works of Sigmund Freud. 17. London: Vintage.

Freud, S., 2001b. Beyond the Pleasure Principle, Group Psychology and Other Works: The Standard Edition of the Complete Psychological Works of Sigmund Freud. 18. London: Vintage.

Greenberg, J., ed. 2003. Trauma at Home after 9/11. Lincoln and London: University of Nebraska Press.

Harry Potter Franchise. 2001-2011. Dir. Various. US/UK.

Hodgin, N., and Thakkar, A., eds. 2017. Scars and Wounds: Film and Legacies of Trauma. London and New York: Palgrave.

Hoge, C., Auchterlonie, J., and Milliken, C., 2006. Mental Health Problems, Use of Mental Health Services and Attrition from Military Service after Returning from Deployment to Iraq or Afghanistan. Journal of the American Medical Association, 295(9), 1023-1032.

Holloway, D., 2008. 9/11 and the War on Terror. Edinburgh: Edinburgh University Press.

Hunt, N., 2010. Memory, War and Trauma. Cambridge and New York: Cambridge University Press.

Hunt, N. and McHale, S., 2010. Understanding Traumatic Stress. London: Sheldon Press.

The Hurt Locker. 2008. Dir. Kathryn Bigelow. US.

Inception. 2010. Dir. Christopher Nolan. US.

In the Valley of Elah. 2007. Dir. Paul Haggis. US.

Kaplan, E. A., 2005. Trauma Culture: The Politics of Terror and Loss in Media and Literature. New Brunswick and London: Rutgers University Press.

Kellner, D., 2010. Cinema Wars: Hollywood Film and Politics in the Bush-Cheney Era. Malden and Oxford: Wiley-Blackwell. 
King, G., 2000. Spectacular Narratives: Hollywood in the Age of the Blockbuster. London and New York: IB Tauris.

King, G., ed. 2005. The Spectacle of the Real: From Hollywood to Reality TV and Beyond. Bristol and Portland: Intellect.

Kirmayer, L., Lemelson, R., and Barad, M., eds. 2007. Understanding Trauma: Integrating Biological, Clinical, and Cultural Perspectives. Cambridge and New York: Cambridge University Press.

Kopka, K., 2018. Cultural Hauntings: Narrating Trauma in Contemporary Films about the Iraq War. Ex-Centric Narratives: Journal of Anglophone Literature, Culture and Media. 2,103-120.

Lacan, J., 2002. Écrits (Trans. B. Fink). New York and London: Norton and Company.

LaCapra, D., 2001. Writing History, Writing Trauma. Baltimore and London: Johns Hopkins University Press.

Luckhurst, R., 2008. The Trauma Question. London and New York: Routledge.

Luckhurst, R., 2010. Beyond Trauma: Torturous Times. European Journal of English Studies, 14(1), 11-21.

Morag, R., 2013. Waltzing with Bashir: Perpetrator Trauma and Cinema. London: I.B. Tauris.

McNally, R., 2003. Remembering Trauma. Cambridge and London: Harvard University Press.

Myers, T., 2003. Slavoj Žižek (Routledge Critical Thinkers). London and New York: Routledge.

Pheasant-Kelly, F., 2013. Fantasy Film Post 9/11. London and New York: Palgrave Macmillan.

Prince, S., 2009. Firestorm: American Film in the Age of Terrorism. New York: Columbia University Press.

Radstone, S., 2003. The War of the Fathers: Trauma, Fantasy and September 11. In J. Greenberg, ed. Trauma at Home after 9/11. Lincoln and London: University of Nebraska Press, 117123. 
Shalev, A., 2007. PTSD: A Disorder of Recovery? In L. Kirmayer, R. Lemelson, and M. Barad, eds. Understanding Trauma: Integrating Biological, Clinical, and Cultural Perspectives. Cambridge and New York: Cambridge University Press, 207-223.

Shutter Island. 2010. Dir. Martin Scorsese. US.

Straw, M., 2011. Ethical Encounters and Passive Spectators: Looking on at Hollywood's War on Terror. In P. Hammond, ed. Screens of Terror: Representations of War and Terrorism in Film and Television since 9/11. Suffolk: Arima Publishing, 51-70.

Toffoletti, K. and Grace, V., 2010. Terminal Indifference: The Hollywood War Film PostSeptember 11. Film-Philosophy, 14(2), 62-83.

Walker, J., 2005. Trauma Cinema: Documenting Incest and the Holocaust. Berkeley and London: University of California Press.

Westwell, G., 2011. In Country: Mapping the Iraq War in Recent Hollywood Combat Movies. In P. Hammond, ed. Screens of Terror: Representations of War and Terrorism in Film and Television since 9/11. Suffolk: Arima Publishing, 19-36.

Žižek S., 2002. Welcome to the Desert of the Real. London and New York: Verso. 